\title{
KEDUDUKAN FATWA DEWAN SYARIAH NASIONAL MAJELIS ULAMA INDONESIA DALAM MENDORONG PERKEMBANGAN BISNIS PERBANKAN SYARIAH (PERSPEKTIF HUKUM PERBANKAN SYARIAH)
}

(Position of The National Sharia Board - Indonesian Council Of Ulema's Fatwa In Stimulate The Development Of Islamic Banking Business - Islamic Banking Law Perspective)

\author{
Ahyar Ari Gayo dan Ade Irawan Taufik \\ Badan Pembinaan Hukum Nasonal Kementerian Hukum dan HAM RI \\ Jl. Mayjen. Soetoyo, Cililitan, Jakarta Timur
}

Naskah diterima: 14 Mei 2012; revisi: 10 Juli 2012; disetujui: 20 Juli 2012

\begin{abstract}
ABSTRAK
Di dalam perbankan syariah, disamping peraturan perundang-undangan, para praktisi perbankan syariah juga memerlukan Fatwa Dewan Syariah Majelis Ulama Indonesia (DSN-MUI) sebagai acuan dalam mejalankan praktek perbankan syariah. Permasalahannya adalah apakah Fatwa DSN-MUI secara langsung mengikat bagi pelaku perbankan syariah. Dengan menggunakan metode penelitian yuridis sosiologis diperoleh jawaban bahwa Fatwa DSN-MUI merupakan perangkat aturan yang bersifat tidak mengikat dan tidak ada paksaan secara hukum bagi sasaran diterbitkannya fatwa untuk mematuhi ketentuan fatwa tersebut, namun di sisi lain, berdasarkan peraturan perundang-undangan yang berlaku, adanya kewajiban bagi regulator (Bank Indonesia) agar materi muatan yang terkandung dalam Fatwa DSN-MUI diserap dan ditransformasikan sebagai prinsip-prinsip syariah dalam materi muatan peraturan perundang-undangan. Keberadaan Fatwa DSN-MUI semakin menunjukan peranannya sebagai pedoman pelaksanaan prinsip-prinsip syariah dalam perbankan syariah sejak diberlakukannya Undang-Undang No. 21 Tahun 2008 tentang Perbankan Syariah. Hambatan dalam penerapan Fatwa DSNMUI dalam kegiatan perbankan syariah, antara lain fatwa yang sulit untuk diterjemahkan atau sulit diaplikasikan dalam peraturan perbankan dan fatwa DSN-MUI yang tidak selaras dengan hukum positif.
\end{abstract}

Kata kunci: Fatwa, DSN-MUI, Perbankan Syariah

\section{ABSTRACT}

In the Islamic banking, besides legislation, the practitioners of Islamic banking also requires the National Sharia Board - Indonesian Council of Ulema's Fatwa (DSN-MUI) as a reference in practice carry out Islamic banking. The problem is is whether the DSN-MUI Fatwa is directly tied to the perpetrators of Islamic banking. By using the methods of sociological juridical research obtained answers that DSN-MUI Fatwa is a set of rules which are not binding and there is no legal compulsion for the target to comply with the fatwa issued the fatwa, but on the other side, based on legislation in force, the obligation for the regulator (Bank Indonesia) that the substance contained in the DSN-MUI Fatwa absorbed and transformed the Islamic principles in the substance of legislation. The presence of DSN-MUI Fatwa has grown from its role as the guidelines for the implementation of sharia principles in Islamic banking since the enactment of Law No. 21 of 2008 on Islamic Banking. Obstacles in the implementation of DSN-MUI fatwa in Islamic banking activities, including fatwas that are difficult to translate or difficult to apply in banking regulation and DSN-MUI fatwa is not aligned with the positive law Keywords: Fatwa, DSN-MUI, Islamic Banking 


\section{A. Pendahuluan}

Terdapat rambu-rambu hukum Islam yang mengatur ketika manusia melakukan kegiatan untuk memenuhi kebutuhan hidupnya. Ramburambu hukum dimaksud, ada yang bersifat pengaturan dari Alquran, Alhadis, peraturan perundang-undangan (ijtihad kolektif), ijma qiyas, istihsan, maslahat mursalah, maqashidus syariah, maupun istilah lainnya dalam teoriteori hukum Islam.. Rambu-rambu pengaturan dalam beraktifitas dimaksud, baik dalam bentuk hukum perbankan, jual beli, asuransi, gadai, utang piutang, maupun dalam bentuk lainnya dalam bidang hukum ekonomi atau ekonomi syariah. ${ }^{1}$

Sejarah pergerakan ekonomi Islam di Indonesia secara formal sebenarnya telah berlangsung sejak tahun 1911, yaitu sejak berdirinya organisasi Syarikat Dagang Islam yang dibidani oleh para entrepreneur dan para tokoh Muslim saat itu. Bahkan jika kita menarik sejarah jauh ke belakang, jauh sebelum tahun 1911, peran dan kiprah para santri (umat Islam) dalam dunia perdagangan cukup besar. Dalam buku Pedlers and Princes, (1955), Clifford Geertz, seorang antropolog dari Amerika Serikat, menyatakan bahwa di Jawa, para santri reformis mempunyai profesi sebagai pedagang atau wirausahawan dengan etos entrepreneurship yang tinggi. Sementara dalam buku "The Religion of Java" (1960), Geertz menulis, "Pengusaha santri (muslim) adalah mereka yang dipengaruhi oleh etos kerja Islam yang hidup di lingkungan di mana mereka bekerja. ${ }^{2}$

Pada dasawarsa terakhir, perhatian umat Islam Indonesia terhadap ajaran ekonomi yang berdasarkan syariah mulai tumbuh dan berkembang. Hal tersebut disebabkan, selain karena sistem ekonomi konvensional ternyata tidak dapat memenuhi harapan, kesadaran umat untuk syariah secara kaffah (menyeluruh) dalam berbagai aspek kehidupan ternyata juga terus meningkat.

Momentum pergerakan ekonomi syariah dimulai ketika lahirnya Bank Muamalat Indonesia pada tahun 1992 sebagai bank pertama di Indonesia yang berlandaskan pada prinsip syariah dalam kegiatan transaksinya. ${ }^{3}$ Kelahiran bank syariah ini kemudian diikuti oleh bankbank lain, baik yang berbentuk full branch maupun yang hanya berbentuk divisi atau unit usaha syariah. Tak ketinggalan, lembaga keuangan lainnya pun, seperti perusahaan asuransi dengan prinsip syariah; pasar modal yang berbasiskan produk syariah dan lembaga pembiayaan non bank dengan prinsip syariah terus bermunculan.

Perkembangan ekonomi syariah dalam bidang usaha perbankan syariah, sampai dengan triwulan III 2010 jumlah bank yang melakukan kegiatan usaha syariah meningkat seiring dengan munculnya pemain-pemain baru baik dalam

Zainuddin Ali, Hukum Ekonomi Syariah, (Jakarta: Sinar Grafika, 2008), hlm. 1.

Agustianto, Implementasi Ekonomi Syariah, sumber: http://www.agustiantocentre.com/?p=459, diakses tanggal 29 April 2011.

3 PT Bank Muamalat Indonesia, Tbk. didirikan pada 24 Rabius Tsani 1412 H atau 1 Nopember 1991, diprakarsai oleh Majelis Ulama Indonesia (MUI) dan Pemerintah Indonesia, dan memulai kegiatan operasinya pada 27 Syawal $1412 \mathrm{H}$ atau $1 \mathrm{Mei}$ 1992. Dengan dukungan nyata dari eksponen Ikatan Cendekiawan Muslim se-Indonesia (ICMI) dan beberapa pengusaha Muslim. Pendirian Bank Muamalat juga menerima dukungan masyarakat, terbukti dari komitmen pembelian saham Perseroan senilai Rp 84 miliar pada saat penandatanganan akta pendirian Perseroan, sumber: http://www.muamalatbank.com/index.php/home/about/profile, diakses tanggal 29 April 2011. 
bentuk Bank Umum Syariah (BUS) maupun Bank Pembiayaan Rakyat Syariah (BPRS). BUS yang pada akhir tahun 2009 berjumlah 6 BUS bertambah 4 BUS dimana 2 BUS merupakan hasil konversi Bank Umum Konvensional dan 2 BUS hasil spin off Unit Usaha Syariahnya (UUS) sehingga jumlah UUS di tahun 2010 ini berkurang menjadi 23 UUS. Peningkatan jaringan kantor BUS dan UUS sampai triwulan III 2010 meningkat sebanyak 387 kantor, peningkatan ini terutama dari pembukaan kantor cabang terutama kantor cabang pembantu. Sedangkan untuk layanan syariah mengalami penurunan sebanyak 652 menjadi 1140 pada triwulan III 2010. ${ }^{4}$

Dalam menghadapi perkembangan ekonomi syariah yang signifikan di Indonesia, diperlukan suatu perangkat peraturan perundangan-undangan yang dapat memberikan kepastian hukum kepada para praktisi ekonomi syariah dalam menjalankan ekonomi syariah. Di dalam konstitusi, kegiatan ekonomi syariah secara implisit didasarkan pada Pasal 29 ayat (1 dan 2) Undang-Undang Dasar Negara Republik Indonesia Tahun 1945, kemudian pengaturan ekonomi syariah di Indonesia tersebar dalam berbagai peraturan perundang-undangan, antara lain Undang-Undang No. 7 Tahun 1989 tentang Peradilan Agama sebagaimana telah diubah dengan Undang-Undang No. 3 Tahun 2006 tentang Perubahan Atas Undang-Undang No. 7 Tahun 1989 tentang Peradilan Agama sebagaimana telah diubah pula dengan UndangUndang No. 50 Tahun 2009 tentang Perubahan Kedua atas Undang-Undang No. 7 Tahun 1989 tentang Peradilan Agama; Undang-Undang No. 7 Tahun 1992 tentang Perbankan sebagaimana telah diubah dengan Undang-Undang No. 10 Tahun 1998 tentang Perubahan atas UndangUndang No. 7 Tahun 1992; Undang-Undang No. 23 Tahun 1992 tentang Bank Indonesia sebagaimana telah diubah dengan UndangUndang No. 3 Tahun 2004 tentang Perubahan Atas Undang-Undang No. 23 Tahun 1992 tentang Bank Indonesia; Undang-Undang No. 8 Tahun 1995 tentang Pasar Modal; Undang-Undang No. 38 Tahun 1999 tentang Pengelolaan Zakat; Undang-Undang No. 41 Tahun 2004 tentang Wakaf; Undang-Undang No. 40 Tahun 2007 tentang Perseroan Terbatas; Undang-Undang No. 21 Tahun 2008 tentang Perbankan Syariah; Undang-Undang No. 19 Tahun 2008 tentang Surat Berharga Syariah Negara; dan peraturan perundang-undangan lainnya dalam bentuk Peraturan Pemerintah, Peraturan Presiden, Peraturan Bank Indonesia, Peraturan Menteri Keuangan maupun Peraturan Bapepam-LK.

Selain peraturan perundang-undangan tersebut di atas, para praktisi ekonomi syariah, masyarakat dan pemerintah (regulator) membutuhkan fatwa-fatwa terkait ekonomi syariah dari para ulama atau lembaga-lembaga atau organisasi-organisasi Islam lainnya yang berkompeten mengeluarkan fatwa-fatwa sebagai suatu pegangan atau petunjuk untuk melaksanakan kegiatan ekonomi syariah. Perkembangan lembaga ekonomi syariah yang demikian cepat harus diimbangi dengan fatwa-fatwa ekonomi syariah yang valid dan akurat. Untuk lebih meningkatkan khidmah dan memenuhi harapan umat yang demikian besar terhadap ekonomi syariah, Majelis Ulama Indonesia (MUI) pada Tahun 1999 telah

Outlook Perbankan Syariah Indonesia 2011, diterbitkan oleh Direktorat Perbankan Syariah Bank Indonesia, 2010, sumber: www.bi.go.id, diakses tanggal 02 Mei 2011. 
membentuk Dewan Syariah Nasional (DSN). Lembagaini, yang beranggotakan paraahlihukum Islam (fuqaha') serta ahli dan praktisi ekonomi, terutama sektor keuangan, bank maupun nonbank, berfungsi untuk melaksanakan tugastugas MUI dalam mendorong dan memajukan ekonomi ummat, di samping itu, lembaga ini pun bertugas, antara lain, untuk menggali, menguji dan merumuskan nilai dan prinsipprinsip hukum Islam (syariah) untuk dijadikan pedoman dalam kegiatan transaksi di lembagalembaga keuangan syariah, serta mengawasi pelaksanaan dan implementasinya.

Sejak berdiri tahun 1999, DSN, telah mengeluarkan lebih dari 80 fatwa tentang ekonomi syariah, antara lain, fatwa tentang giro, tabungan, murabahah, jual beli saham, istishna', mudharabah, musyarakah, ijarah, wakalah, kafalah, hawalah, uang muka dalam murabahah, sistem distribusi hasil usaha dalam lembaga keuangan syariah, diskon dalam murabahah, sanksi atas nasabah mampu yang menunda-nunda pembayaran, pencadangan penghapusan aktiva produktif dalam Lembaga KeuanganSyariah, al-qaradh, investasireksadana syariah, pedoman umum asuransi syariah, jual beli istisna' paralel, potongan pelunasan dalam murabahah, safe deposit box, raha (gadai), rahn emas, ijarah muntahiyah bit tamlik, jual beli mata uang, pembiayaan pengurusan haji di Lembaga Keuangan Syariah, pembiayaan rekening koran syariah, pengalihan hutang, obligasi syariah, obligasi syariah mudharabah, Letter of Credit (LC) impor syariah, LC untuk ekspor, Sertifikat Wadiah Bank Indoensia, Pasar Uang antar Bank Syariah, sertifikat investasi mudharabah (IMA), asuransi haji, pedoman umum penerapan prinsip syariah di pasar modal, obligasi syariah ijarah, kartu kredit, dan sebagainya.
Permasalahannya adalah apakah para pelaku ekonomi syariah dapat secara langsung menjadikan Fatwa MUI sebagai dasar untuk menerapkan prinsip-prinsip ekonomi syariah sebagai dasar operasional kegiatan perbankan syariah atau dituangkan terlebih dahulu ke dalam peraturan perundang-undangan, sehingga diakui keberadaannya dan mempunyai kekuatan hukum mengikat. Mengingat Fatwa MUI tidak termasuk ke dalam jenis peraturan perundangundangan sebagaimana tersebut dalam Pasal 7 Undang-Undang No. 12 Tahun 2011 tentang Pembentukan Peraturan Perundang-undangan.

\section{B. Permasalahan}

1. Bagaimana kedudukan Fatwa DSN-MUI dalam perspektif hukum perbankan syariah di Indonesia?

2. Bagaimana Peran fatwa DSN-MUI dalam mendorong pelaksanaan ekonomi syariah dalam bidang usaha perbankan syariah di Indonesia?

3. Faktor apa saja yang menjadi hambatan dalam penerapan Fatwa DSN-MUI dalam mendorong pelaksanaan bidang usaha perbankan syariah di Indonesia?

\section{Metode Penelitian}

Penelitian ini merupakan penelitian yuridis sosiologis, yaitu meneliti tentang keberadaan Fatwa-fatwa MUI dan perkembangan ekonomi syariah dan bagaimana hubungan hukum antara fatwa MUI dan pelaksanaan ekonomi syariah di Indonesia dengan peraturan perundangundangan yang berlaku. Data penelitian yang digunakan dalam penelitian ini berupa data primer dan data sekunder. Data primer yang digunakan yaitu data yang diperoleh langsung dari objek penelitian yang diperoleh melalui metode instrumen wawancara kepada pihak 
regulator dalam hal ini Bank Indonesia dan pelaku usaha perbankan syariah ${ }^{5}$ dan juga para pakar yang mempunyai kompetensi di bidang ekonomi syariah.

\section{Pembahasan}

\section{Kedudukan Fatwa Dewan Syariah Nasional - Majelis Ulama Indonesia Dalam Perspektif Hukum Perbankan Syariah di Indonesia}

\section{a. Konsepsi Fatwa DSN MUI}

Pengertian fatwa secara terminologis, sebagaimana dikemukakan oleh Zamakhsyari adalah penjelasan hukum syara' tentang suatu masalah atas pertanyaan seseorang atau kelompok. Menurut as-Syatibi, fatwa dalam arti al-iftaa berarti keterangan-keterangan tentang hukum syara' yang tidak mengikat untuk diikuti. Menurut Yusuf Qardawi, fatwa adalah menerangkan hukum syara' dalam suatu persoalan sebagai jawaban atas pertanyaan yang diajukan oleh peminta fatwa (mustafi) baik secara perorangan atau kolektif. ${ }^{6}$

Fatwa merupakan suatu keputusan hukum atas suatu masalah yang dilakukan oleh seorang ulama yang berkompeten baik dari segi ilmu atau kewaraannya. Fatwa dikeluarkan baik diminta ataupun tidak, karena itu perkembangan fatwa dalam sistem hukum Islam sangat penting seiring dengan permasalahan sosial yang semakin hari semakin banyak dan kompleks dibandingkan dengan permasalahan yang terjadi pada masa Nabi Muhammad, SAW, dan para sahabat. Permasalahan yang dialami Rasulullah dan para sahabatnya tidak serumit yang dihadapi sekarang, disisi lain Allah, SWT telah mencukupkan wahyuNya dan hadits yang disampaikan Rasulullah untuk memecahkan permasalahan-permasalahan yang ada. ${ }^{7}$

Keberadaan pihak-pihak pemberi fatwa di Indonesia, pada awalnya pada abad ke-20 dikeluarkan oleh ulama secara individu. Pada pertengahan kedua abad ke-20, beberapa fatwa mulai dikeluarkan oleh para ulama secara berkelompok. Pada tahun 1926, para ulama tradisionalis mendirikan organisasi Nahdlatul Ulama (NU) dan mulai mengeluarkan fatwa untuk para pengikutnya melalui sebuah lajnah yang dinamakan Lajnah Bahts al-Masa'il. Sedangkan para ulama modernis yang memiliki pendirian ijtihad secara langsung merujuk al-Quran dan al-Sunnah, mendirikan Muhammadiyah pada tahun 1912. Pada awalnya Muhammadiyah tidak memberi penekanan dalam persoalan fatwa, namun pada tahun 1927, organisasi itu membentuk panitia khusus diberi nama Majelis Tarjih. Tugas utama majelis ini meng-

\footnotetext{
5 Pelaku usaha perbankan syariah yang diwawancarai, yaitu PT. Bank BNI Syariah; PT. Bank Syariah Mandiri; PT. Bank Danamon Indonesia Unit Usaha Syariah; PT. Bank Mega Syariah; PT. Bank BJB Syariah; PT. Bank Maybank Syariah Indonesia (dua responden, yaitu Direktur Kepatuhan dan Kepala Divisi Risk Management) dan PT. Bank Tabungan Negara Unit Usaha Syariah. Pemilihan 8 (delapan) responden lembaga perbankan syariah tersebut di atas sebagai sample untuk diwawancarai adalah didasarkan pada pemikiran: 1) Bahwa jumlah total populasi lembaga perbankan syariah di Indonesia adalah berjumlah 34 (tiga puluh empat) lembaga perbankan syariah (diluar Bank Pembiayaan Syariah), dengan perincian, bank umum syariah berjumlah 11 (sebelas) dan bank dengan pelayanan unit usaha syariah berjumlah 23 (dua puluh tiga) unit usaha syariah); 2) Jangka waktu penelitian yang relatif pendek, sehingga tidak memungkinkan untuk mewawancarai seluruh populasi lembaga perbankan syariah, maka jumlah responden dibatasi sampai dengan $25 \%$ dari jumlah total populasi, yaitu kurang lebih 8 (delapan) sample responden yang dianggap mereprentasikan total populasi.

6 Ma'ruf Amin, Fatwa Dalam Sistem Hukum Islam, (Jakarta: Elsas, 2008), hlm. 19.

7 Ridwan Nurdin, Kedudukan Fatwa MUI Dalam Pengembangan Ekonomi Syariah di Indonesia, makalah disampaikan dalam diskusi dengan Penulis, tanggal 17 Juni 2011.
} 
kaji permasalahan yang berhubungan dengan keagamaan (agama Islam) secara umum, dan menerapkan hukumnya secara khusus berlandaskan syariat Islam. ${ }^{8}$

Pada perkembangan berikutnya, tahun 1975, dibentuk Majelis Ulama Indonesia. Majelis ini beranggotakan para ulama dari pelbagai kalangan, baik kalangan tradisionalis maupun modernis. Sejak pendiriannya hingga sekarang, MUI telah mengeluarkan banyak fatwa, baik berkaitan dengan masalah ritual keagamaan, pernikahan, kebudayaan, politik, ilmu pengetahuan, maupun transaksi ekonomi. Perkembangan berikutnya, MUI menganggap perlu mendirikan Dewan Syariah Nasional (DSN), untuk menumbuh kembangkan penerapan nilai-nilai syariah, mengeluarkan fatwa yang berhubungan dengan jenis-jenis kegiatan, produk dan jasa keuangan syariah, termasuk juga bank-bank syariah. ${ }^{9}$

DSN adalah lembaga yang dibentuk oleh MUI yang secara struktural berada di bawah MUl. Tugas DSN adalah menjalankan tugas MUI dalam menangani masalah-masalah yang berhubungan dengan ekonomi syariah, baik yang berhubungan dengan aktivitas lembaga keuangan syariah ataupun yang lainnya. ${ }^{10}$ Untuk melaksanakan tugas utama tersebut, DSN memiliki otoritas untuk: ${ }^{11}$

a. Mengeluarkan fatwa yang mengikat Dewan Pengawas Syariah di masing-masing Lembaga Keuangan Syariah dan menjadi dasar tindakan hukum pihak terkait.

b. Mengeluarkan fatwa yang menjadi landasan bagi ketentuan/peraturan yang dikeluarkan oleh institusi yang berhak, seperti Kementerian Keuangan dan Bank Indonesia.

c. Memberikan dukungan dan/atau mencabut dan menyokong nama-nama yang akan duduk sebagai Dewan Pengawas Syariah pada suatu Lembaga Keuangan Syariah.

d. Mengundang para ahli untuk menjelaskan suatu masalah yang diperlukan dalam pembahasan ekonomi syariah, termasuk otoritas moneter/lembaga keuangan dalam maupun luar negeri.

e. Memberikan rekomendasi kepada Lembaga keuangan Syariah untuk menghentikan penyimpangan dari fatwa yang telah dikeluarkan oleh Dewan Syariah Nasional.

f. Mengusulkan kepada institusi yang berhak untuk mengambil tindakan apabila perintah tidak didengar.

\section{b. Konsepsi Perbankan Syariah}

Ekonomi syariah adalah ekonomi yang didasarkan pada petunjuk-petunjuk al-Qur'an dan Hadits. Sedangkan menurut Abdul Manan, bahwa yang dimaksud dengan ekonomi syariah adalah perbuatan atau kegiatan usaha yang dilaksanakan menurut prinsip syariah yang meliputi bank syariah, lembaga keuangan mikro syariah, asuransi syariah, reasuransi syariah, reksadana syariah, obligasi syariah dan surat berharga berjangka menengah syariah, sekuritas syariah, pembiayaan syariah, pegadaian syariah, dana pensiun lembaga keuangan syariah dan bisnis syariah. ${ }^{12}$

M. Cholil Nafis, Teori Hukum Ekonomi Syariah, (Jakarta: UI Press, 2011), hlm. 4.

Ibid., hlm. 6

Ibid., hlm. 82.

Ibid., hlm. 89.

M. Arsyad Harahap, Ekonomi Syariah dan Ruang Lingkup Pembahasannya, sumber: http://ekonomisyariah.blog. gunadarma.ac.id/2010/05/25/ekonomi-syari\%E2\%80\%99ah-dan-ruang-lingkup-pembahasannya-oleh-drsm-arsyad-harahap/, diakses pada tanggal 29 April 2011. Lihat juga Agustianto, Blueprint Ekonomi Syariah di Indonesia, sumber: http://www.agustiantocentre.com/?p=783, diakses tanggal 29 April 2011 
Di dalam Penjelasan Pasal 49 huruf (i) UndangUndang No. 7 Tahun 1989 tentang Peradilan AgamasebagaimanatelahdiubahdenganUndangUndang No. 3 Tahun 2006 tentang Perubahan Atas Undang-Undang No. 7 Tahun 1989 tentang Peradilan Agama sebagaimana telah diubah pula dengan Undang-Undang No. 50 Tahun 2009 tentang Perubahan Kedua atas UndangUndang No. 7 Tahun 1989 tentang Peradilan Agama, merumuskan "ekonomi syariah" adalah perbuatan atau kegiatan usaha yang dilaksanakan menurut prinsip syari'ah, meliputi: bank syari'ah; asuransi syari'ah; reasuransi syari'ah; reksadana syari'ah; obligasi syari'ah dan surat berharga berjangka menengah syari'ah; sekuritas syari'ah; pembiayaan syari'ah; pegadaian syari'ah; dana pensiun lembaga keuangan syari'ah; bisnis syari'ah; dan lembaga keuangan mikro syari'ah.

Berdasarkan Pasal 1 angka (1) UndangUndang No. 21 Tahun 2008 tentang Perbankan Syariah, bahwa yang dimaksud dengan Perbankan Syariah adalah segala sesuatu yang menyangkut tentang Bank Syariah dan Unit Usaha Syariah, mencakup kelembagaan, kegiatan usaha, serta cara dan proses dalam melaksanakan kegiatan usahanya, kemudian di dalam Pasal 1 angka (7) undang-undang tersebut disebutkan bahwa yang dimaksud Bank Syariah adalah Bank yang menjalankan kegiatan usahanya berdasarkan Prinsip Syariah dan menurut jenisnya terdiri atas Bank Umum Syariah dan Bank Pembiayaan Rakyat Syariah. Prinsip syariah itu sendiri berdasarkan Pasal 1 angka (12) adalah prinsip hukum Islam dalam kegiatan perbankan berdasarkan fatwa yang dikeluarkan oleh lembaga yang memiliki kewenangan dalam penetapan fatwa di bidang syariah.
Pada dasarnya sistem perbankan syariah memiliki tiga ciri yang mendasar, yaitu (a) prinsip keadilan, (b) menghindari kegiatan yang dilarang, dan (c) memperhatikan aspek kemanfaatan. Dalam pelaksanaan operasional sistem perbankan syariah akan tercermin prinsip ekonomi syariah dalam bentuk nilai-nilai yang secara umum dapat dibagi dalam dua persektif, yaitu mikro dan makro. Nilai-nilai syariah dalam perspektif mikro menekankan aspek kompetensi / profesionalisme dan sikap amanah; sedangkan dalam perspektif makro nilai-nilai syariah menekankan aspek distribusi, pelarangan riba dan kegiatan ekonomi yang tidak memberi manfaat secara nyata kepada sistem perekonomian. ${ }^{13}$

Merujuk pada pasal 19 ayat (1) UndangUndang No. 21 Tahun 2008, disebutkan bahwa kegiatan usaha Bank Umum Syariah meliputi:

a. menghimpun dana dalam bentuk Simpanan berupa Giro, Tabungan, atau bentuk lainnya yang dipersamakan dengan itu berdasarkan Akad wadi'ah atau Akad lain yang tidak bertentangan dengan Prinsip Syariah;

b. menghimpun dana dalam bentuk Investasi berupa Deposito, Tabungan, atau bentuk lainnya yang dipersamakan dengan itu berdasarkan Akad mudharabah atau Akad lain yang tidak bertentangan dengan Prinsip Syariah;

c. menyalurkan Pembiayaan bagi hasil berdasarkan Akad mudharabah, Akad musyarakah, atau Akad lain yang tidak bertentangan dengan Prinsip Syariah;

d. menyalurkan Pembiayaan berdasarkan Akad murabahah, Akad salam, Akad istishna', atau Akad lain yang tidak bertentangan dengan Prinsip Syariah;

13 Zainuddin Ali, Hukum Perbankan Syariah, (Jakarta: Sinar Grafika, 2008), hlm. 20. 
e. menyalurkan Pembiayaan berdasarkan Akad qardh atau Akad lain yang tidak bertentangan dengan Prinsip Syariah;

f. menyalurkan Pembiayaan penyewaan barang bergerak atau tidak bergerak kepada Nasabah berdasarkan Akad ijarah dan/atau sewa beli dalam bentuk ijarah muntahiya bittamlik atau Akad lain yang tidak bertentangan dengan Prinsip Syariah;

g. melakukan pengambilalihan utang berdasarkan Akad hawalah atau Akad lain yang tidak bertentangan dengan Prinsip Syariah;

h. melakukan usaha kartu debit dan/atau kartu pembiayaan berdasarkan Prinsip Syariah;

i. membeli, menjual, atau menjamin atas risiko sendiri surat berharga pihak ketiga yang diterbitkan atas dasar transaksi nyata berdasarkan Prinsip Syariah, antara lain, seperti Akad ijarah, musyarakah, mudharabah, murabahah, kafalah, atau hawalah;

j. membeli surat berharga berdasarkan Prinsip Syariah yang diterbitkan oleh pemerintah dan/atau Bank Indonesia;

k. menerima pembayaran dari tagihan atas surat berharga dan melakukan perhitungan dengan pihak ketiga atau antar pihak ketiga berdasarkan Prinsip Syariah;

I. melakukan Penitipan untuk kepentingan pihak lain berdasarkan suatu Akad yang berdasarkan Prinsip Syariah;

m. menyediakan tempat untuk menyimpan barang dan surat berharga berdasarkan Prinsip Syariah;

n. memindahkan uang, baik untuk kepentingan sendiri maupun untuk kepentingan Nasabah berdasarkan Prinsip Syariah;

o. melakukan fungsi sebagai Wali Amanat berdasarkan Akad wakalah; p. memberikan fasilitas letter of credit atau bank garansi berdasarkan Prinsip Syariah; dan

q. melakukan kegiatan lain yang lazim dilakukan di bidang perbankan dan di bidang sosial sepanjang tidak bertentangan dengan Prinsip Syariah dan sesuai dengan ketentuan peraturan perundang-undangan.

\section{c. Kedudukan Fatwa DSN MUI dalam Perspektif Hukum Perbankan Syariah}

Ada beberapa dasar pertimbangan disahkannya Rancangan Undang-Undang Perbankan Syariah menjadi Undang-Undang antara lain: Pertama, secara yuridis, kehadiran UndangUndangPerbankansyariahadalahdidasarkanpada Pancasila dan UUD Negara Republik Indonesia Tahun 1945 (UUD 1945). Jadi, penerapan hukum ekonomi syariah di Indonesia memiliki dasar yang sangat kuat. Ketentuan Pasal 29 ayat (1) UUD 1945 dengan tegas menyatakan bahwa Negara berdasar atas Ketuhanan Yang Maha Esa.

Dalam pasal 29 ayat (2) UUD 1945 disebutkan bahwa negara menjamin kemerdekaan tiap-tiap penduduk untuk memeluk agamanya masingmasing dan untuk beribadat menurut agama dan kepercayaannya itu. Kata "menjamin" sebagaimana termaktub dalam ayat (2) pasal 29 UUD 1945 tersebut bersifat "imperatif", artinya negara berkewajiban secara aktif melakukan upaya-upaya agar tiap-tiap penduduk dapat memeluk agama dan beribadat menurut agama dan kepercayaannya itu. Sebenarnya, melalui ketentuan pasal 29 ayat (2) UUD 1945, seluruh syariat Islam, khususnya yang menyangkut bidang-bidang hukum muamalat, pada dasarnya dapat dijalankan secara sah dan formal oleh kaum muslimin, baik secara langsung maupun tidak langsung, dengan jalan diadopsi dalam hukum positif nasional. 
Keharusan tiadanya materi konstitusi dan peraturan perundang-undangan yang bertentangan dengan nilai-nilai ke-Tuhanan Yang Maha Esa tersebut adalah konsekuensi diterapkannya Prinsip Ketuhanan Yang Maha Esa sebagai salah prinsip dasar penyelenggaraan negara, oleh karenanya kehadiran kedua undang-undang ekonomi syariah tersebut, tidak bertantangan dengan Pancasila, UUD 1945 dan tidak mengganggu keutuhan NKRI. ${ }^{14}$

Merujuk beberapa negara saat ini, fungsi fatwa dalam sebuah negara dapat dibedakan melalui tiga fungsi utama. Pertama, negara yang menjadikan syariah Islam sebagai dasar dan undang-undang negara yang dilaksanakan secara menyeluruh dan sempurna, maka fatwa memainkan peranan sangat penting. Kedua, negara yang mengaplikasikan hukum sekuler, maka fatwa tidak mempunyai peranan dan tidak berfungsi dalam negara. Ketiga, negara yang menggabungkan penerapan hukum sekuler dan hukum Islam, maka fungsi fatwa lebih bertumpu dalam ruang lingkup hukum Islam saja. Indonesia adala negara yang mengaplikasikan pola pemerintahan ketiga, sehingga menjadikan kajian fatwa di Indonesia begitu menarik. ${ }^{15}$

Berdasarkan Pasal 7 ayat (1) Undang-Undang No. 12 Tahun 2011 tentang Pembentukan Peraturan Perundang-undangan, jenis dan hierarkhi peraturan perundang-undangan adalah sebagai berikut:
a. Undang-Undang Dasar Negara Republik Indonesia Tahun 1945;
b. Ketetapan Majelis Permusyawaratan Rakyat;
c. Undang-Undang/Peraturan Pemerintah Pengganti Undang-Undang;
d. Peraturan Pemerintah;
e. Peraturan Presiden;
f. Peraturan Daerah Provinsi; dan
g. Peraturan Daerah Kabupaten/Kota.

Kemudian di dalam Pasal 8 ayat (1 dan 2) Undang-Undang No. 12 tahun 2011 disebutkan pula bahwa keberadaan jenis peraturan perundang-undangan selain sebagaimana dimaksud dalam Pasal 7 ayat (1) mencakup peraturan yang ditetapkan oleh Majelis Permusyawaratan Rakyat, Dewan Perwakilan Rakyat, Dewan Perwakilan Daerah, Mahkamah Agung, Mahkamah Konstitusi, Badan Pemeriksa Keuangan, Komisi Yudisial, Bank Indonesia, Menteri, badan, lembaga, atau komisi yang setingkat yang dibentuk dengan Undang-Undang atau Pemerintah atas perintah Undang-Undang, Dewan Perwakilan Rakyat Daerah Provinsi, Gubernur, Dewan Perwakilan Rakyat Daerah Kabupaten/Kota, Bupati/Walikota, Kepala Desa atau yang setingkat diakui keberadaannya dan mempunyai kekuatan hukum mengikat sepanjang diperintahkan oleh peraturan perundang-undangan yang lebih tinggi atau dibentuk berdasarkan kewenangan.

Apabila merujuk jenis dan hierarkhi sebagaimana tersebut dalam Undang-Undang No. 12 Tahun 2011 tersebut, maka posisi Fatwa DSN - MUI tidak merupakan suatu jenis peraturan perundang-undangan yang mempunyai kekuatan mengikat secara umum.

Kemudian bagaimana kedudukan fatwa DSNMUI dalam peraturan perundang-undangan di Indonesia. Kedudukan Fatwa DSN-MUI terdapat dalam berbagai macam peraturan perundangundangan.

\footnotetext{
14 Agustianto, Inklusivisme Ekonomi Syariah (Rekleksi menanti Kelahiran UU SBSN dan UU Perbankan Syariah), sumber: http://www.agustiantocentre.com/?p=816, diakses pada tanggal 29 April 2011.

15 M. Cholil Nafis, Op.Cit., hlm. 3.
} 
Dalam catatan sejarah sejak berdirinya MUI sampai dengan sekarang, telah banyak fatwa dan nasihat MUI sebagai produk pemikiran hukum Islam yang terserap ${ }^{16}$ dalam berbagai Peraturan Perundang-undangan khususnya di bidang Hukum Ekonomi Syariah. Indikator yang mendukung kecenderungan tersebut dapat dilihat dari lahirnya beberapa Peraturan Perundangundangan, antara lain:

\section{1) Undang-Undang Nomor 7 Tahun 1992 tentang Perbankan: \\ Di dalam Pasal 6 huruf $(\mathrm{m})$ undang-undang} tersebut, disebutkan bahwa usaha bank umum meliputi menyediakan pembiayaan bagi nasabah berdasarkan prinsip bagi hasil sesuai dengan ketentuan yang ditetapkan dalam Peraturan Pemerintah. Sebagai peraturan pelaksana dari ketentuan pasal tersebut, diberlakukan Peraturan Pemerintah No. 72 Tahun 1992 tentang Bank Berdasarkan Prinsip Bagi Hasil. Dari ketentuan Pasal 6 huruf $(\mathrm{m})$ dan PP No. 72 Tahun 1992, meski tidak disebutkan secara eksplisit kata-kata bank syariah, namun dapat diartikan bahwa bank dengan prinsip bagi hasil adalah suatu ketentuan prinsip muamalah berdasarkan syariah;

2) Undang-Undang Nomor 10 Tahun 1998 tentang Perubahan atas Undang-Undang No. 7 Tahun 1992 tentang Perbankan;

Undang-Undang No. 10 Tahun 1998 merupakan suatu titik awal pengakuan perbankan syariah secara eksplisit dalam peraturan perundang-undangan. Di dalam Undang-Undang No. 10 Tahun 1998 disebutkan secara tegas kata "Prinsip Syariah" di dalam Pasal 1 angka $(3,4,12$, $13,18)$, Pasal 6 huruf (M), Pasal 7 huruf (c), Pasal 8 ayat (1\&2), Pasal 11 ayat (1\&3);
3) Undang-Undang Nomor 40 Tahun 2007 tentang Perseroan Terbatas;

Dalam Pasal 109 Undang-Undang Nomor 40 Tahun 2007 dinyatakan:

(1) Perseroan yang menjalankan kegiatan usaha berdasarkan prinsip syariah selain mempunyai Dewan Komisaris wajib mempunyai Dewan Pengawas Syariah.

(2) Dewan Pengawas Syariah sebagaimana dimaksud pada ayat (1) terdiri atas seorang ahli syariah atau lebih yang diangkat oleh RUPS atas rekomendasi Majelis Ulama Indonesia.

Dewan Pengawas Syariah sebagaimana dimaksud pada ayat (1) bertugas memberikan nasihat dan saran kepada Direksi serta mengawasi kegiatan Perseroan agar sesuai dengan prinsip syariah.

4) Undang-Undang Nomor 19 Tahun 2008 tentang Surat Berharga Syariah Negara;

Dalam Pasal 25 Undang-Undang Undang-

Undang Nomor 19 Tahun 2008 dinyatakan:

"Dalam rangka penerbitan SBSN, Menteri meminta fatwa atau pernyataan kesesuaian SBSN terhadap prinsip prinsip syariah dari lembaga yang memiliki kewenangan dalam penetapan fatwa di bidang syariah."

Dalam penjelasan Pasal 25 tersebut dinyatakan bahwa:

"Yang dimaksud dengan "lembaga yang memiliki kewenangan dalam menetapkan fatwa di bidang syariah" adalah Majelis Ulama Indonesia atau lembaga lain yang ditunjuk Pemerintah."

5) Undang-Undang Nomor 21 Tahun 2008 tentang Perbankan Syariah;

Dalam Pasal 26 Undang-Undang Nomor 21 Tahun 2008 dinyatakan: 
(1) Kegiatan usaha sebagaimana dimaksud dalam Pasal 19, Pasal 20, dan Pasal 21 dan/ atau produk dan jasa syariah, wajib tunduk kepada Prinsip Syariah.

(2) Prinsip Syariah sebagaimana dimaksud pada ayat (1) difatwakan oleh Majelis Ulama Indonesia.

(3) Fatwa sebagaimana dimaksud pada ayat (2) dituangkan dalam Peraturan Bank Indonesia.

(4) Dalam rangka penyusunan Peraturan Bank Indonesia sebagaimana dimaksud pada ayat (3), Bank Indonesia membentuk komite perbankan syariah.

(5) Ketentuan lebih lanjut mengenai tata cara pembentukan, keanggotaan, dan tugas komite perbankan syariah sebagaimana dimaksud pada ayat (4) diatur dengan Peraturan Bank Indonesia.

(6) Undang-Undang Nomor 10 Tahun 2011 tentang Perubahan atas Undang-Undang Nomor 32 Tahun 1997 tentang Perdagangan Berjangka Komoditi.

Dalam Pasal II angka 1 (a) Undang-Undang tersebut dinyatakan:

"Sebelum dibentuknya Peraturan Perundangundangan yang mengatur tentang perdagangan berjangka komoditi syariah, maka penyelenggaraan Kontrak Derivatif Syariah ditetapkan berdasarkan Fatwa Dewan Syariah Nasional - Majelis Ulama Indonesia."

6) Surat Keputusan Direksi Bank Indonesia No. 32/34/1999

Dalam Pasal 31 Surat Keputusan tersebut disebutkan bahwa "untuk melaksanakan kegiatan-kegiatan usahanya, bank umum syariah diwajibkan untuk memperhatikan fatwa DSNMUI", kemudian di dalam Surat Keputusan tersebut dinyatakan bahwa dalam hal bank akan melakukan kegiatan usaha, jika ternyata usaha yang dimaksudkan belum difatwakan oleh DSN, maka bank wajib meminta persetujuan DSN sebelum melaksanakan kegiatan usaha tersebut.

Berdasarkan hasil penelitian, sebagai pihak regulator kegiatan perbankan syariah, Bank Indonesia, juga mempunyai keterikatan dengan Fatwa yang dihasilkan oleh DSN-MUI. Dalam membuat Peraturan Bank Indonesia, Bank Indonesia menggunakan Fatwa DSN-MUI sebagai bahan referensi dalam penyusunan Peraturan Bank Indonesia dan juga Surat Edaran yang bersifat eksternal. Dalam praktek pembuatan PBI terkait dengan perbankan syariah Bank Indonesia hanya boleh merujuk Fatwa DSN-MUI dalam menyusun $\mathrm{PBI}$, dan tidak merujuk pada fatwa yang dikeluarkan oleh institusi selain DSN-MUI. ${ }^{17}$

Apabila melihat kedudukan fatwa DSN-MUI yang terdapat dalam peraturan perundangundangan, maka fatwa DSN-MUI merupakan perangkat aturan kehidupan masyarakat yang bersifat mengikat bagi Bank Indonesia sebagai regulator, yaitu adanya kewajiban agar materi muatan yang terkandung dalam Fatwa MUI dapat diserap dan ditransformasikan dalam merumuskan prinsip-prinsip syariah dalam bidang perbankan syariah menjadi materi muatan Peraturan Perundang-undangan yang memiliki kekuatan hukum dan mengikat umum. Oleh karena itu Bank Indonesia, tidak dapat membuat suatu peraturan terkait perbankan syariah yang bertentang dengan prinsip-prinsip syariah yang ditentukan dalam fatwa DSN-MUI, selain itu hanya fatwa DSN-MUI yang dapat dijadikan pedoman dalam pembuatan Peraturan Bank Indonesia, artinya Bank Indonesia tidak boleh mengacu

17 Instrumen Penelitian: Wawancara Responden/Informan dengan Kepala Biro Penelitian, Pengembangan dan Pengaturan Perbankan Syariah, Direktorat Perbankan Syariah Bank Indonesia. 
pada fatwa yang diterbitkan oleh institusi lainnya meskipun institusi yang mengeluarkan fatwa tersebut adalah institusi yang berkompeten dalam mengeluarkan fatwa.

Berdasarkan hasil penelitian yang dilakukan terhadap lembaga perbankan syariah, ditemukan bahwa lembaga perbankan syariah mempunyai keterikatan terhadap fatwa yang dikeluarkan oleh DSN-MUI. Menurut lembaga perbankan syariah yang diwawancarai, keterikatan terhadap fatwa DSN-MUI dikarenakan adanya peraturan perundang-undangan yang mewajibkan lembaga perbankan syariah untuk patuh terhadap fatwa DSN-MUI, selain hal tersebut, Fatwa DSN-MUI merupakan syarat yang paling mendasar dalam pembuatan dan pengembangan produk baru yang dikeluarkan oleh lembaga perbankan syariah serta operasional kegiatan perbankan syariah.

Yeni Salma Barinti mengatakan bahwa fatwa DSN-MUI mempunyai kekuatan hukum yang mengikat sehingga harus dipatuhi oleh pelaku ekonomi syariah. Kekuatan hukum ini didasarkan pada beberapa ketentuan yang berlaku dalam peraturan perundang-undangan, baiksecara langsung maupun tidak langsung. Secara langsung adalah disebut dengan jelas dalam peraturan bahwa fatwa menjadi prinsip syariah yang harus dipatuhi, apabila tidak dipatuhi, pelaku ekonomi syariah akan dikenakan sanksi administrasi. Secara tidak langsung adalah disebutkannya peran Dewan Pengawas Syariah (DPS) yang harus berada di lembaga perbankan syariah. Dalam melaksanakan perannya sebagai pengawas syariah, DPS harus berpedoman kepada fatwafatwa yang diterbitkan oleh DSN-MUI. ${ }^{18}$

Apabila melihat pada persepsi lembaga perbankan syariah dan keterangan ahli tersebut di atas, maka kekuatan mengikat dari fatwa DSNMUI tersebut bukan saja terjadi ketika fatwa DSN-MUI tersebut menjadi materi muatan dalam Peraturan Bank Indonesia, namun juga diperlukan sebagai pedoman bagi pihak perbankan syariah dalam dalam pembuatan dan pengembangan produk baru yang dikeluarkan serta operasional kegiatan perbankan syariah serta kewajiban Dewan Pengawas Syariah di lembaga perbankan syariah untuk berpedoman kepada fatwa DSNMUI.

Pembentukan fatwa merupakan tuntutan yang harus dipenuhi oleh DSN-MUI dalam rangka menciptakan kepastian hukum penyelenggaraan kegiatan ekonomi syariah di Indonesia, mengupayakan agar kegiatan ekonomi syariah di Indonesia dapat berjalan dengan tertib, dan tentunya dengan adanya fatwa tersebut diharapkan kegiatan ekonomi syariah di Indonesia dapat berkembang dengan lebih cepat. Pada awal pelaksanaan kegiatan ekonomi syariah di Indonesia belum terdapat hukum nasional atau Peraturan Perundang-undangan yang mengatur kegiatan ekonomi syariah tersebut, sehingga Fatwa MUI sangat dibutuhkan eksistensinya sebagai landasan hukum untuk menutupi kekosongan hukum di bidang ekonomi syariah.

\section{Peran Fatwa DSN-MUI dalam mendorong pelaksanaan ekonomi syariah dalam bidang usaha perbankan syariah di Indonesia}

Hampir seluruh fatwa-fatwa yang dikeluarkan oleh DSN-MUI terserap dalam bentuk Peraturan Bank Indonesia yang akan mengikat seluruh perbankan syariah dan pelaku fiqih muamalah, meskipun beberapa fatwa

18 Instrumen Penelitian: Wawancara Responden/Informan dengan Yeni Salma Barlinti (Dosen Fakultas Hukum Universitas Indonesia). 
diadaptasi dan digabung menjadi satu Peraturan Bank Indonesia. ${ }^{19}$

Dalam praktik pelaksanaan perbankan syariah, Bank Indonesia telah banyak mengeluarkan peraturan sebagai tuntunan pelaksanaan prinsip-prinsip syariah. Fatwa pada dasarnya memiliki sifat sesuai dengan keadaan dan situasi tempat dan mengikuti pemahaman kontemporer, sehingga fatwa dapat mengalami perubahan. Apabila terjadi perubahan fatwa DSN-MUI terhadap permasalahan tertentu, maka hal ini bukan tidak mungkin berakibat pada perubahan ketentuan Bank Indonesia. Namun dalam prakteknya, berdasarkan data penelitian belum ada perubahan Peraturan Bank Indonesia akibat perubahan fatwa dari DSN-MUI. ${ }^{20}$

Peraturan Bank Indonesia No. 7/46/ $\mathrm{PBI} / 2005$ tentang Akad Penghimpunan Uang dan Penyalurannya bagi Bank yang Melaksanakan Transaksi Berdasarkan Prinsip Syariah telah diganti dengan Peraturan Bank Indonesia No. 9/19/PBI/2007 tentang Pelaksanaan Prinsip Syariah dalam Kegiatan Penghimpunan Uang dan Penyalurannya serta Layanan Jasa Bank Syariah. Penggantian ini dilakukan untuk menyesuaikan dengan keputusan fatwa yang dikeluarkan oleh DSN-MUI, dalam hal inilah proses menjadikan fatwa berkekuatan mengikat, yaitu terjadinya 'transformasi' hukum Islam menjadi hukum nasional. ${ }^{21}$

Diterbitkannya fatwa bahwa bunga bank adalah riba nasi'ah yang diharamkan oleh MUI pada tanggal 24 Januari 2004 menjadi salah satu pendorong pelaksanaan perbankan syariah di Indonesia. Pasca kehadiran fatwa tersebut berpengaruh terhadap beralihnya sebagian nasabah yang beragama Islam ke bank syariah.

Keberadaan fatwa DSN-MUI semakin menunjukkan peranannya dalam sebagai pedoman pelaksanaan prinsip-prinsip syariah dalam perbankan syariah sejak diberlakukannya Undang-Undang No. 21 Tahun 2008 tentang Perbankan Syariah.Undang-Undang No. 21 Tahun 2008 mewajibkan para stakeholders untuk memperhatikan dan menyesuaikan kegiatan-kegiatan usaha sesuai dengan prinsipprinsip syariah yang tersebut dalam Fatwa yang dikeluarkan DSN-MUI.

Sebagai undang-undang yang khusus mengatur perbankan syariah, dalam Undang-Undang No. 21 Tahun 2008 diatur mengenai masalah kepatuhan syariah (syariah compliance) yang kewenangannya berada pada Majelis Ulama Indonesia (MUI) yang direpresentasikan melalui Dewan Pengawas Syariah (DPS) yang harus dibentuk pada masing-masing Bank Syariah dan Unit Usaha Syariah. Untuk menindaklanjuti implementasi fatwa yang dikeluarkan MUI ke dalam Peraturan Bank Indonesia, di dalam internal Bank Indonesia dibentuk Komite Perbankan Syariah, yang keanggotaannya terdiri atas perwakilan dari Bank Indonesia, Departemen Agama, dan unsur masyarakat yang komposisinya berimbang. ${ }^{22}$

Dalam proses implementasi atau penuangan fatwa ke dalam Peraturan Bank Indonesia, Bank Indonesia menerbitkan Peraturan Bank Indonesia No. 10/32/PBI/2008 tentang Komite Perbankan Syariah, yang bertugas menjabarkan fatwa MUI yang berhubungan dengan perban-

\footnotetext{
19 M. Cholil Nafis, Op.Cit., hlm. 137.

20 Instrumen Penelitian: Wawancara Responden / Informan dengan Kepala Biro Penelitian, Pengembangan dan Pengaturan Perbankan Syariah, Direktorat Perbankan Syariah Bank Indonesia

21 M. Cholil Nafis, Op.Cit., hlm. 239.

22 Lihat Penjelasan Umum Undang-Undang No. 21 Tahun 2008.
} 
kan syariah, memberikan sumbangan dalam rangka penyerapan fatwa dalam Peraturan Bank Indonesia dan melaksanakan pembangunan industri perbankan syariah.

Penyusunan ketentuan Bank Indonesia dimulai dengan riset atau penelitian, selanjutnya akan dilakukan diskusi dengan stakeholders antara lain industri perbankan syariah dan juga dengan MUI dalam hal terkait pembahasan mengenai fatwa.

Peranan Fatwa DSN-MUI sebagai pemberi pedoman prinsip-prinsip syariah tidak hanya dalam tataran untuk diserap dalam peraturan Bank Indonesia atau syariah compliance dalam internal lembaga perbankan syariah, namun juga pada hakikatnya fatwa-fatwa DSN-MUI telah diserap dalam Undang-Undang No. 21 Tahun 2008 dalam hal jenis-jenis transaksi yang disebutkan dalam undang-undang tersebut.

Pola-pola penyerapan jenis-jenis transaksi dalam fatwa DSN-MUI ke dalam produk-produk perbankan syariah terlihat sebagai berikut:

1. Pengimpunan Dana, berupa Giro Syariah (Fatwa DSN No. 1/DSN-MUI/IV/2000 tentang Giro); Tabungan Syariah (Fatwa DSN-MUI yang mendasarinya Fatwa DSN No. 2/DSNMUI/IV/2000 tentang Tabungan); Deposito Syariah (Fatwa DSN No. 3/DSN-MUI/IV/2000 tentang Deposito).

2. Penyaluran Dana, berupa Pembiayaan atas dasar akad mudharabah (Fatwa DSN No. 7/DSN-MUI/IV/2000 tentang Pembiayaan Mudharabah (Qiradh)); Pembiayaan atas dasar akad musyarakah. (Fatwa DSN No. 8/ DSN-MUI/IV/2000 tentang Pembiayaan Musyarakah); Pembiayaan atas dasar akad murabahah (Fatwa DSN No. 4/DSNMUI/IV/2000 tentang Murabahah; Fatwa DSN No. 10/DSN-MUI/IV/2000 tentang
Wakalah;Fatwa DSN No. 13/DSN-MUI/ IX/2000 tentang Uang Muka Dalam Murabahah;Fatwa DSN No. 16/DSN-MUI/ IX/2000 tentang Diskon dalam Murabahah;Fatwa DSN No. 23/DSN-MUI/III/2002 tentang Potongan Pelunasan dalam Murabahah; Fatwa DSN No. 46/DSN-MUI/ II/2005 tentang Potongan Tagihan Murabahah (Khashm Fi Al Murabahah); Fatwa DSN No.47/DSN-MUI/II/2005tentang Penyelesaian Piutang Murabahah bagi Nasabah Tidak Mampu Membayar; Fatwa DSN No. 48/DSN-MUI/II/2005 tentang Penjadwalan Kembali tentang Tagihan Murabahah;Fatwa DSN No. 49/DSN-MUI/II/2005 tentang Konversi Akad Murabahah); Pembiayaan atas dasar akad salam (Fatwa DSN No. 5/DSNMUI/IV/2000 tentang Jual Beli Salam); Pembiayaan atas dasar akad istishna (Fatwa DSN No. 6/DSN-MUI/IV/2000 tentang Jual Beli Istishna', dan Fatwa DSN No. 22/DSNMUI/III/2002 tentang Jual Beli Istishna' Paralel); Pembiayaan atas dasar akad ijarah (Fatwa DSN No. 9/DSN-MUI/IV/2000 tentang Pembiayaan ljarah dan FatwaDSN No. 27/ DSN-MUI/III/2002 tentang al-ljarah alMuntahiyah bi al- Tamlik); Pembiayaan atas dasar akad qardh (Fatwa DSN No. 19/DSNMUI/IV/2001 tentang Al qardh); Pembiayaan Multijasa (Fatwa DSN No. 44/DSN-MUI/ VIII/2004 tentang Pembiayaan Multijasa).

3. Pelayanan Jasa, berupa Letter of credit (L/C) Impor syariah (Fatwa DSN No. 34/DSNMUI/IX/2002 tentang Letter of Credit(L/C) Impor Syariah); Bank Garansi Syariah (Fatwa DSN Fatwa DSN No. 11/DSN-MUI/IV/2000 tentang Kafalah); Penukaran Valuta Asing (Sharf), Fatwa DSN No. 28/DSN-MUI/III/2002 tentang Jual Beli Mata Uang (Al Sharf). 
Peranan fatwa DSN-MUI berdasarkan data penelitian, pada prakteknya sebagian besar fatwa DSN-MUI yang telah diterbitkan telah menjawab kebutuhan perbankan syariah, meskipun masih terdapat beberapa hal yang belum terjawab atau belum tersedianya fatwa DSN-MUI dalam mendukung pengembangan produk baru dan kegiatan operasional perbankan syariah.

Peranan Fatwa DSN-MUI dalam mendorong pelaksanaan perbankan syariah dapat diindikasikan juga dengan banyaknya bank umum syariah dan bank dengan unit usaha syariah yang memulai kegiatan operasinya setelah MUI membentuk Dewan Syariah Nasional. Sebelum periode tahun 2008 jumlah bank umum syariah hanya berjumlah tiga bank, pada tahun 2011 ini jumlah bank umum syariah meningkat menjadi 11 (sebelas) bank umum syariah, begitu pula dengan BPR Syariah, sebelum periode tahun 2008 jumlah BPR Syariah hanya berjumlah 114 bank, pada tahun 2011 ini jumlah BPR Syariah meningkat menjadi 154 bank.

\section{Hambatan dalam penerapan Fatwa DSN-MUI dalam mendorong pelak- sanaan ekonomi syariah dalam bidang usaha perbankan syariah di Indonesia}

Hampir seluruh fatwa-fatwa yang dikeluarkan oleh DSN-MUI terserap dalam bentuk Peraturan Bank Indonesia yang akan mengikat seluruh perbankan syariah dan masyarakat pelaku perbankan syariah, namun ada beberapa fatwa yang sulit untuk diterjemahkan dalam peraturan perbankan sehingga hal ini menjadi kendala dalam pengembangan usaha perbankan syariah.

Berdasarkan data penelitian yang diperoleh ada beberapa kendala penerapan Fatwa DSNMUI dalam pelaksanaan perbankan syariah. Dalam hal ini Bank Indonesia mengakui bahwa kendala yang dihadapi yaitu hal yang terkait dengan hukum positif yang berlaku yang sering tidak sejalan dengan hukum Islam. Dalam hukum positif hanya mengenal transaksi utang piutang dalam perbankan, sehingga fatwa MUI terkait mudharabah, musyarakah, ijarah dan lainnya tidak dapat dilaksanakan secara utuh.

Pihak lembaga perbankan syariah juga mengakui bahwa ada kendala-kendala yang dihadapi dalam penerpan fatwa DSN-MUI, antara lain:

a. Paradigma nasabah yang belum mengenal produk dan operasional perbankan syariah;

b. Regulasi belum selaras dengan fatwa, seperti produk IMBT apabila dilaksanakan sesuai dengan fatwa maka objek IMBT harus atas nama bank, apabila demikian maka akan menimbulkan cost yang tinggi seperti regulasi pajak;

c. Perbedaan persepsi antara DSN-MUI dan Bank Indonesia mengenai fatwa ekonomi syariah;

d. Adanya fatwa DSN-MUI yang tidak terlalu detail sehingga untukhal-hal teknisterkadang menimbulkan pertanyaan / perdebatan;

e. Adanya fatwa yang belum aplikatif, seperti fatwa DSN-MUI No. 15/DSN-MUI/IX/2000 tentang Prinsip Distribusi Hasil Usaha Dalam LKS;

f. Belum dapat mengadaptasi prinsip-prinsip syariah dalam pergerakan moneymarket yang ekspansif

g. Tidak semua fatwa ekonomi relevan dari sisi bisnis. Sebab, LKS tidak akan membuat sebuah produk yang kurang menguntungkan dan tidak dapat diserap oleh pihak ketiga;

h. Kendala Support Pemerintah. Seringkali kebijakan pemerintah menjadi kendala bagi terlaksananya Fatwa DSN-MUI oleh LKS. Misalnya double tax yang pernah diberlakukan untuk akad Murabahah (sebab 
barang harus dibeli dulu oleh bank dan kemudian baru dijual kepada nasabah);

i. Kendala dalam produk dengan akad musyarakah, PBI mensyaratkan pembatasan proyeksi pendapatan minimal $80 \%$ terkait pembiayaan, maka jika kurang dari $80 \%$ maka akan masuk NPf.

Sedangkan kendala-kendala yang dihadapi perbankan syariah dalam mengembangkan usahanya berdasarkan persepsi lembaga perbankan syariah dan Bank Indoensia, antara lain:

a. Mindset deposan yang masih berpikir secara konvensional dan masih ada kesan di sebagian masyarakat bahwa bank syariah bersifat ekslusif dalam artian bahwa bank syariah hanya ditujukan untuk masyarakat muslim dan melibatkan kaum yang beragama muslim saja, hal ini dikarenakan sosialisasi perbankan syariah yang belum optimal. Oleh sebab fatwa menggunakan istilah-istilah berbahasa arab (terutama jenis akad) dan $\mathrm{PBI}$ juga menggunakan istilah yang sama, maka perlu waktu bagi perbankan untuk melakukan sosialisasi kepada pihak ketiga (masyarakat) terhadap produk-produk perbankan yang menggunakan istilah berbahasa arab. Selain itu, minimnya budget untuk marketing dan promosi juga menjadi kendala perbankan syariah untuk semakin dikenal di mata masyarakat luas;

b. Peraturan untuk membuat iklim investasi di industri syariah masih kurang fleksibel, aturan perpajakan dan pertumbuhan produk dan jasa baru belum didukung maksimal dengan landasan hukum yang memadai dalam bentuk fatwa DSN-MUI maupun PBI; c. Keterbatasan sumber daya manusia yang memahami produk dan sistem syariah;

d. Masih kurangnya modal yang dimiliki perbankan syariah;

e. Lembaga arbitrase syariah nasional yang ada sekarang bukan dibentuk oleh pemerintah tetapi oleh MUI. Hal ini menyebabkan lembaga ini tidak memiliki kewenangan yang mengikat;

f. Fasilitas dari pemerintah terkait penyelesaian pembiayaan bermasalah;

g. Kendala tekhnis, berupa sistem informasi (IT). Semisal mekanisme bagi hasil (Profit Share) kepada pihak ketiga yang harusnya fluktuatif setiap bulan (tergantung keuntungan bank). Sementara ini masih terkendala sistem yang ter "set up" tetap (fix) setiap bulan.

Menurut Yeni Salma Barlinti, kendala-kendala dalam penerapan fatwa ekonomi syariah, antara lain disebabkan tidak semua pelaku ekonomi syariah mengetahui adanya fatwa DSN-MUI; masih banyaknya anggapan bahwa fatwa DSN-MUI tidak memiliki kekuatan hukum; fatwa DSN-MUI tidak dapat diterapkan secara sempurna karena adanya hukum-hukum yang telah berlaku yang harus dipatuhi oleh pelaku ekonomi syariah dan masih banyak peraturan perundang-undangan yang belum menunjang pelaksanaan fatwa DSN-MUI. ${ }^{23}$

Merujuk perihal kendala-kendala sebagaimana tersebut di atas, maka letak permasalahan secara garis besar terletak pada:

a. Produk fatwa DSN-MUI itu sendiri yang belum menjawab kebutuhan kegiatan perbankan syariah;

${ }^{23}$ Instrumen Penelitian: Wawancara Responden/Informan dengan Yeni Salma Barlinti (Dosen Fakultas Hukum Universitas Indonesia). 
b. Proses 'penterjemaahan' atau 'penyerapan' Fatwa DSN-MUI ke dalam peraturan perundang-undangan;

c. Kesiapan pihak perbankan syariah untuk menyesuaikan kegiatan operasional dan produk perbankan mereka dengan Fatwa DSN-MUI;

Berdasarkan kendala-kendala dalam penerapan fatwa DSN-MUI tersebut dalam pelaksanaan ekonomi syariah, maka untuk meminimalkan kendala tersebut yang dapat dilakukan antara lain yaitu:

a. Perkembangan perbankan syariah yang dinamis tidak diikuti oleh kedinamisan fatwa DSN-MUI yang dapat menjawab kebutuhan perbankan syariah. Oleh karena itu perlunya dilibatkan lebih aktif partisipasi stakeholders (dalam hal ini Bank Indonesia dan lembaga perbankan syariah) oleh DSN-MUI dalam setiap penyusunan Fatwa DSN-MUI, sehingga fatwa-fatwa yang dihasilkan dapat menjawab kebutuhan perbankan syariah dan dalam proses 'penterjemaahan' dan 'penyerapan' tidak menimbulkan multitafsir dan dapat langsung diimplementasikan sehingga aspek kehati-hatian dalam kegiatan perbankan syariah dapat terjaga.

b. Peningkatan kualitas sumber daya manusia dari pihak perbankan syariah perlu dilakukan sebagai langkah aktif dari pihak perbankan syariah untuk siap dan faham terhadap prinsip-prinsip perbankan syariah. Hal ini mengingat masih banyak sumber daya manusia dari pihak perbankan syariah yang masih menggunakan perspektif prinsip perbankan konvensional ketika menjalankan perbankan syariah, sehingga apabila tetap dengan menggunakan perspektif ini, maka akan menimbulkan kesulitan untuk mene- rapkan prinsip perbankan syariah secara murni.

\section{E. Penutup}

\section{Kesimpulan}

Fatwa DSN-MUI merupakan perangkat aturan kehidupan masyarakat yang bersifat tidak mengikat dan tidak ada paksaan secara hukum bagi sasaran diterbitkannya fatwa untuk mematuhi ketentuan fatwa tersebut. Namun di sisi lain, berdasarkan peraturan perundang-undangan yang berlaku, khususnya Undang-Undang No. 21 Tahun 2008 tentang Perbankan Syariah, melalui pola-pola tertentu, adanya kewajiban bagi regulator dalam hal ini Bank Indonesia agar materi muatan yang terkandung dalam Fatwa MUI dapat diserap dan ditransformasikan dalam merumuskan prinsipprinsip syariah dalam bidang perekonomian dan keuangan syariah menjadi materi muatan Peraturan Perundang-undangan yang memiliki kekuatan hukum dan mengikat umum.

Diterbitkannya fatwa yang menetapkan bahwa bunga bank adalah riba nasi'ah yang diharamkan oleh MUI menjadi salah satu pendorong pelaksanaan perbankan syariah di Indonesia, selain itu keberadaan fatwa DSNMUI semakin menunjukan peranannya sebagai pedoman pelaksanaan prinsip-prinsip syariah dalam perbankan syariah sejak diberlakukannya Undang-Undang No. 21 Tahun 2008 tentang Perbankan Syariah, yang mewajibkan para stakeholders untuk memperhatikan dan menyesuaikan kegiatan-kegiatan usaha sesuai dengan prinsip-prinsip syariah yang tersebut dalam Fatwa yang dikeluarkan DSN-MUI. Peranan Fatwa DSN-MUI dalam mendorong pelaksanaan perbankan syariah dapat diindikasikan juga dengan banyaknya bank umum syariah dan 
bank dengan unit usaha syariah yang memulai kegiatan operasinya setelah MUI membentuk Dewan Syariah Nasional.

Dalam penerapan Fatwa DSN-MUI terdapat beberapa hambatan yang ditemui dalam kegiatan perbankan syariah, antara lain fatwa yang sulit untuk diterjemahkan atau sulit diaplikasikan dalam peraturan perbankan, fatwa DSN-MUI yang tidak selaras dengan hukum positif dan beberapa kendala lainnya.

\section{Saran}

Pelibatan yang lebih aktif dan partisipasi stakeholders amat diperlukan (dalam hal ini Bank Indonesia dan lembaga perbankan syariah) oleh DSN-MUI dalam setiap penyusunan Fatwa DSN-MUI, sehingga fatwa-fatwa yang dihasilkan dapat langsung diimplementasikan sehingga aspek kehati-hatian dalam kegiatan perbankan syariah dapat terjaga.

Dukungan pemerintah dan DPR juga diperlukan dalam merancang peraturan perundangundangan yang lebih harmonis dalam mendukung pelaksanaan transaksi perbankan syariah.

Sosialisasi dan edukasi yang lebih intensif mengenai produk-produk perbankan syariah harus terus dilakukan kepada masyarakat luas, dan juga para praktisi perbankan syariah sehingga perbankan syariah dapat berkembang lebih cepat

\section{DAFTAR PUSTAKA}

\section{Buku}

Ali, Zainuddin, Hukum Ekonomi Syariah, (Jakarta: Sinar Grafika, 2008).

\section{Sinar Grafika, 2008).}

Amin, Ma'ruf, Fatwa Dalam Sistem Hukum Islam, (Jakarta: Elsas, 2008).

Fatah, Rohadi Abdul, Analisis Fatwa Keagamaan Dalam Fikih Islam, (Jakarta: Bumi Aksara, 2006).
Nafis, M. Cholil, Teori Hukum Ekonomi Syariah, (Jakarta: UI Press, 2011).

Rohilina, Wisam dan Yusuf Wibisono, Perbankan Syariah Mengokohkan Fondasi Menuju Pertumbuhan Tinggi Yang Berkelanjutan, dalam Indonesia Syariah Economic Outlook (ISEO) 2001, Yusuf Wibisono (Ed.), (Jakarta: Lembaga Penerbit Fakultas Ekonomi Universitas Indonesia, 2011).

Sjafi'i, Antonio, Bank Syariah Dari Teori Ke Praktek, (Jakarta: Tazkia Cendekia-Gema Insani Pers, 2001).

Soekanto, Soerjono, Pengantar Penelitian Hukum, (Jakarta: UI Press, 1986).

Zahrah, Muhammad Abu, Ushul Fiqh, (Jakarta: PT. Pustaka Firdaus, 1999).

Tim Penyusun Kamus Pusat Pembinaan dan Pengembangan Bahasa, Kamus Besar Bahasa Indonesia.

\section{Makalah / Artikel / Prosiding / Hasil Penelitian}

Badan Pengawas Pasar Modal dan Lembaga Keuangan Kementerian Keuangan Republik Indonesia, "Laporan Tahunan (Annual Report) Tahun 2009".

Nurdin, Ridwan, Kedudukan Fatwa MUI Dalam Pengembangan Ekonomi Syariah di Indonesia (makalah).

\section{Internet}

Agustianto, "Implementasi EkonomiSyariah", http:// www.agustiantocentre.com/?p=459, (diakses 29 April 2011).

Agustianto, "Blueprint EkonomiSyariah di Indonesia", http://www.agustiantocentre.com/?p=783, (diakses 29 April 2011).

Agustianto, "Ekonomi Syariah Sebagai Solusi", http:// www.agustiantocentre.com/?p=761, (diakses 29 April 2011).

Agustianto, "Inklusivisme Ekonomi Syariah (Rekleksi menanti Kelahiran UU SBSN dan UU Perbankan Syariah)", http://www.agustiantocentre. com/?p=816, (diakses 29 April 2011).

Agustianto, "Blueprint EkonomiSyariah di Indonesia", http://www.agustiantocentre.com/?p=783, (diakses 29 April 2011).

Dewan Syari'ah Nasional dan Dewan Pengawas Syariah, www.scrib.com/doc/57565656/ Makalah-Dewan-Syari'ah-Nasional-Dan-DewanPengawas-Syari'ah 
Direktorat Perbankan Syariah Bank Indonesia, "Outlook Perbankan Syariah Indonesia 2011", www.bi.go.id

Faradibah, "Kedudukan Fatwa MUI", sumber: http://freearsy.wordpress.com/2009/07/10/ kedudukan-fatwa-mui/, (diakses 29 April 2011).

http://www.muamalatbank.com/index.php/home/ about/profile, (diakses 29 April 2011).

http://www.takaful.com/index.php/profile/list/, (diakses 29 April 2011).

Profil MUI, sumber: www.mui.or.id, (diakses 29 April 2011).
M. Arsyad Harahap, "Ekonomi Syariah dan Ruang Lingkup Pembahasannya", http:// ekonomisyariah.blog.gunadarma.ac.id/2010/ 05/25/ekonomi-syari\%E2\%80\%99ah-dan-ruanglingkup-pembahasannya-oleh-drs-m-arsyadharahap/, (diakses 29 April 2011).

Statistik Perbankan Indonesia (Indonesian Banking Statistics), Direktorat Perizinan dan Informasi Perbankan Bank Indonesia, Vol. 9, No. 8, Juli 2011

Tentang Dewan Syariah Nasional, sumber sumber: www.mui.or.id 